\title{
Economics of high-rise construction: the feasibility of skyscrapers building in the Russian cities
}

\author{
Artur Petrov ${ }^{*}$ and Daria Petrova ${ }^{2}$ \\ ${ }^{1}$ Tyumen Industrial University, Melnikaite street, 72-221, Tyumen, Russia \\ ${ }^{2}$ Federal University named after the first President of Russia B.N. Yeltsin, Ekaterinburg, Chapaev \\ street, 16a-511, Ekaterinburg, Russia
}

\begin{abstract}
The article considers the economic aspects of constructing highrise buildings in the world and in Russia. Data on the number of high-rise buildings in Russian cities with a million population are presented. It is proved that interest in high-rise construction in Russia has been formed only in Moscow and partly in St. Petersburg and Yekaterinburg. The analysis showed that the reason for this is the expensiveness of high-rise construction. According to the enlarged macro-calculation, the cost of building $1 \mathrm{~m}^{2}$ of the area of the Federation Towers complex (Moscow City) is about $2710 \$ / \mathrm{m}^{2}$. Practically a possibility of return on investments in the foreseeable time interval exists only in Moscow. For the regions of Russia this task is rather complicated. Population density in regional Russian cities is quite low, business entities do not have the necessary financial resources for investing in high-rise construction, and investments from abroad absent.
\end{abstract}

\section{Introduction}

High-rise construction has become fashionable in the last 30-50 years practically all over the world. Projects of buildings with a height of more than $1000 \mathrm{~m}$ are no longer surprising. According to [1] today in the world there are 8 non-technical buildings with a height of more than $500 \mathrm{~m} ; 23$ buildings with a height of more than $400 \mathrm{~m} ; 236$ buildings with a height of more than $300 \mathrm{~m} ; 1317$ buildings with a height of more than $200 \mathrm{~m} ; 4238$ buildings with a height of more than $150 \mathrm{~m}$. These facts form an opinion on the practical and economic expediency of building skyscrapers. However, the Russian experience does not confirm this conclusion. In fact, by the end of 2017, only 40 buildings with a height of more than $150 \mathrm{~m}$ (less than $1 \%$ of analogues in the world) have been built or are in the active phase of construction in Russian cities. What are the reasons of this situation? As a working hypothesis of the study, the results of which are presented in the article, the economic entities' lack of economic interest in the high-rise construction in Russian cities is considered.

\section{Methods}

\footnotetext{
* Corresponding author: artigpetrov@,yandex.ru
} 


\subsection{Initial assumptions}

The construction of skyscrapers and urban population density are weakly connected with each other. It is known that the most densely populated city in the world is Manila (Philippines). The average population density in this city is 41511 people $/ \mathrm{km}^{2}$, and in Manila City (9th district) this indicator reached 71263 people $/ \mathrm{km}^{2}$ in 2015 [2]. In the world there are a number of cities with an average population density of more than 20,000 people $/ \mathrm{km}^{2}$ (Mumbai, Dhaka, Kathmandu, etc.), but there are practically no skyscrapers in these cities. At the same time, there are cities in the world that have many high-rise buildings and the population density is very high in all these cities.

\subsection{Factors contributing to the choice of high-rise building strategy in the city}

The works [3] clearly indicate that the most important reason for constructing high-rise buildings in the city is the desire of developers to attract «hot money» of investors to the city. So it was in American cities at the dawn of high-rise construction. Now the same situation is repeated in the cities of South-East Asia, Near East and Middle East. Another significant factor is the rapid growth of the economy, which requires huge volumes of office and residential construction, preferably of high quality and with a high level of individuality [4]. High-rise construction meets these basic requirements.

\subsection{High-rise construction in Russia}

As at December 2017, in Russia only 40 buildings with a height of more than $150 \mathrm{~m}$ have been constructed or are in the active construction phase [5] (36 of them in Moscow, 3 in Ekaterinburg and 1 in St. Petersburg). Moscow and partly St. Petersburg and Yekaterinburg are leading in high-rise construction in the country (Table 1).

Table 1. Statistics of high-rise buildings (more than 20 floors) in Russian cities with a population of more than 1 million people [5]

\begin{tabular}{|l|c|c|}
\hline \multicolumn{1}{|c|}{ City } & $\begin{array}{c}\text { Number of buildings } \\
\text { with more than 20 floors }\end{array}$ & $\begin{array}{c}\text { The total number of floors } \\
\text { in buildings } \\
\text { with more than 20 floors }\end{array}$ \\
\hline Moscow & 1039 & 25712 \\
\hline St. Petersburg & 553 & 13124 \\
\hline Yekaterinburg & 217 & 5411 \\
\hline Novosibirsk & 117 & 2818 \\
\hline Samara & 75 & 1775 \\
\hline Perm & 70 & 1640 \\
\hline Krasnoyarsk & 67 & 1593 \\
\hline Rostov-on-Don & 58 & 1280 \\
\hline Kazan & 41 & 921 \\
\hline Ufa & 41 & 920 \\
\hline Voronezh & 34 & 809 \\
\hline Chelyabinsk & 29 & 658 \\
\hline Nizhny Novgorod & 24 & 556 \\
\hline Volgograd & 16 & 385 \\
\hline Omsk & 2 & 43 \\
\hline
\end{tabular}




\subsection{Establishment of a statistical relationship between the height of tall buildings and the fiscal capacity of Russian cities}

In order to form a general idea of the relationship between the city's economy and the demand for high-rise construction, we will use regression analysis methods of the connection between the predictor and the resultant (Table 2). As a predictor (influence factor) we used the indicator of fiscal capacity; as a resultant - the characteristics presented in Table 1.

Table 2. Fiscal capacity of Russian cities with a population of more than 1 million people

\begin{tabular}{|l|c|c|c|c|c|}
\hline \multirow{2}{*}{ City } & Populatio & \multirow{2}{*}{$\begin{array}{c}\text { Population } \\
\text { density, } \\
\text { n, people }\end{array}$} & \multicolumn{2}{c|}{$\begin{array}{c}\text { Municipal } \\
\text { pudget (2017), bln. } \\
\text { rub. }\end{array}$} & $\begin{array}{c}\text { Specific budget } \\
\text { expendi-tures } \\
\text { (2017), }\end{array}$ \\
\cline { 5 - 6 } & & rub./pers. \\
\hline Moscow & 12380664 & 4833 & 1996.0 & 2211.0 & 178.58 \\
\hline St. Petersburg & 5281579 & 3764 & 502.87 & 572.69 & 108.43 \\
\hline Novosibirsk & 1602915 & 3170 & 36.13 & 36.92 & 23.03 \\
\hline Yekaterinburg & 1455904 & 3111 & 38.10 & 39.10 & 26.86 \\
\hline Nizhny Novgorod & 1264075 & 3078 & 29.65 & 32.72 & 25.88 \\
\hline Kazan & 1231878 & 1915 & 20.28 & 20.97 & 17.02 \\
\hline Chelyabinsk & 1198858 & 2262 & 30.24 & 30.64 & 25.56 \\
\hline Omsk & 1178391 & 2079 & 15.43 & 16.23 & 13.77 \\
\hline Samara & 1169719 & 2160 & 26.13 & 27.97 & 23.91 \\
\hline Rostov-on-Don & 1125299 & 3229 & 34.91 & 37.42 & 33.25 \\
\hline Ufa & 1115560 & 1576 & 26.11 & 26.25 & 23.53 \\
\hline Krasnoyarsk & 1082933 & 2765 & 28.73 & 29.35 & 27.10 \\
\hline Perm & 1048005 & 1310 & 24.50 & 25.50 & 24.33 \\
\hline Voronezh & 1039801 & 1743 & 19.02 & 21.06 & 20.25 \\
\hline Volgograd & 1015586 & 1182 & 20.37 & 20.57 & 20.25 \\
\hline
\end{tabular}

Regression models constructed according to the data of Table 1 and 2 are shown in Fig. 1. The statistical relationship exists $\left(R^{2}=0.911\right.$ for Fig. $1 A$ and $R^{2}=0.902$ for Fig. 1B).

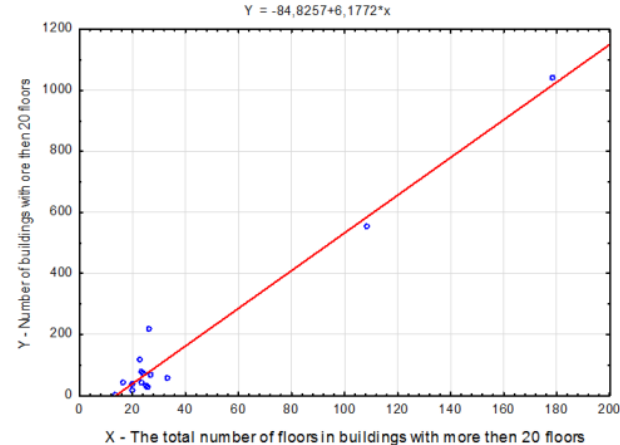

a) Number of buildings with more than 20 floors in city

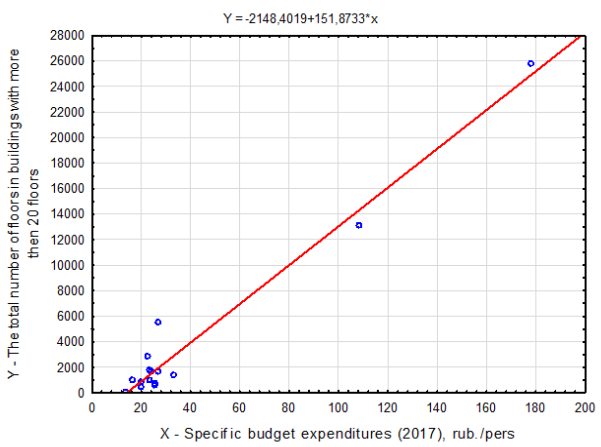

b) The total number of floors in buildings with more than 20 floors in city

Fig. 1. Influence of fiscal capacity on the investment attractiveness of Russian cities with a population of one million people from the position of high-rise construction 
It can be argued that high-rise constructing has chances for development in cities, fiscal capacity of which is relatively high. However, this is not a final, but only an auxiliary conclusion, leading to the main idea of research.

\subsection{Ideology and research tasks}

Using the example of Moscow International Business Center (Moscow City) [6], it is necessary to consider the ideology of formation of investment attractiveness of building brand-new high-rise constructions cluster. The business center management sources told that $\$ 12$ bln. have already invested in MIBS [7]. According to the chief architect of Moscow S. Kuznetsov, to end the building \$ 3 bln. more should be invested. The final cost can make up to $\$ 15 \mathrm{bln}$. How comparable are these costs to global analogs and are there any chances to recoup investments within a reasonable time?

For the purpose of proving the hypothesis of the lack of economic entities' economic interest in the management of high-rise construction in the Russian cities, three tasks were solved:

- Ascertainment of the structure of the cost of construction the $1 \mathrm{~m}^{2}$ area in different countries of the world;

- Comparison of the results of the enlarged macrocalculation of the cost of the construction $1 \mathrm{~m}^{2}$ area of the MIBC with world analogues;

- Assessment of the possibility of the MIBS construction project recoupment by the attracted business.

\section{Results}

\subsection{Ascertainment of the structure of the cost of construction the $1 \mathrm{~m} 2$ area in different countries of the world}

Fig. 2 presents data on the existing cost ranges for the construction of $1 \mathrm{~m}^{2}$ in high-rise buildings in London [8], the cities of the UAE, Shanghai, Melbourne, New York. Note that the regional gap in the cost of construction can be threefold [9]. Fig. 3 shows the structure of the cost of high-rise construction of $1 \mathrm{~m}^{2}$ area in London $\left(4100 \$ / \mathrm{m}^{2}\right)$, Riyadh $\left(2900 \$ / \mathrm{m}^{2}\right)$, Shanghai $\left(1300 \$ / \mathrm{m}^{2}\right)$.

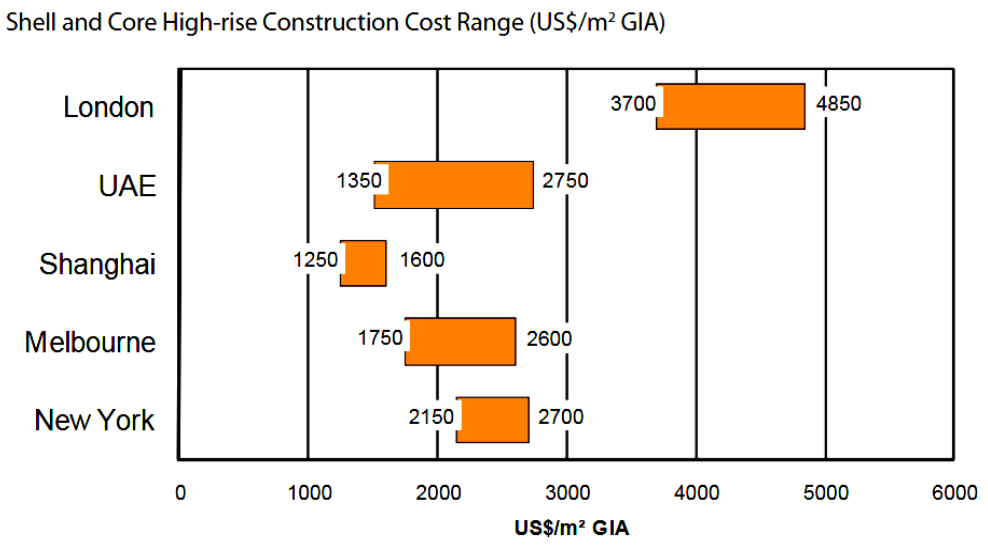

Fig. 2. Differences in the cost of high-rise construction in the cities of the world [9] 


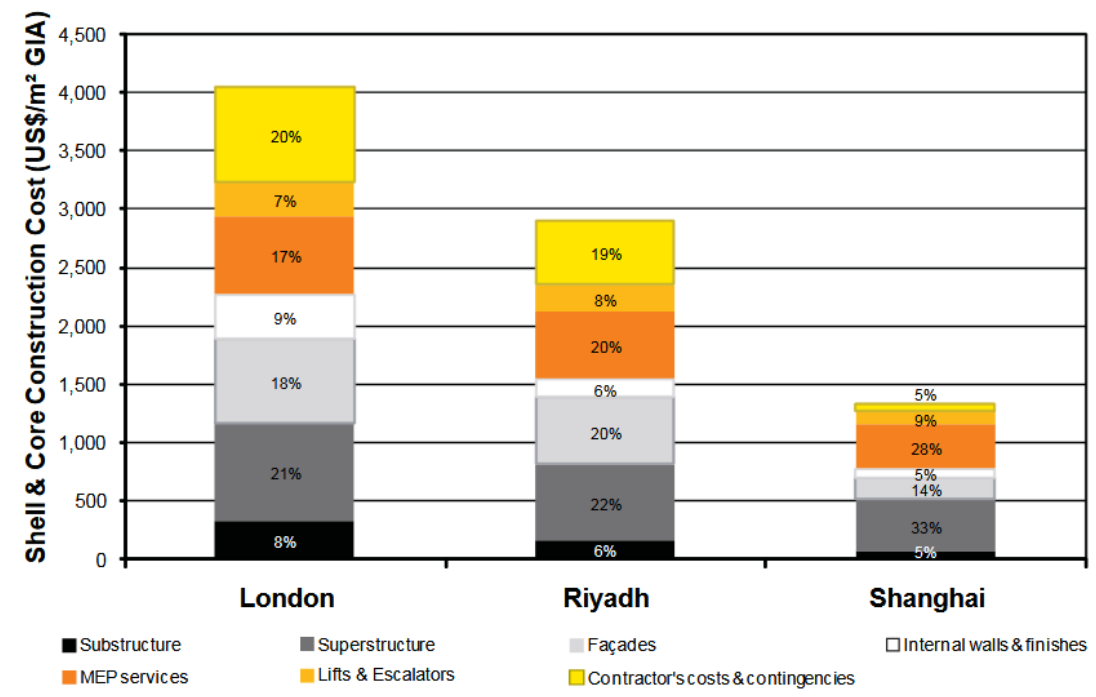

Fig. 3. Typical Elemental Build-up of Shell \& Core Construction Costs for landmark High-rise Office Buildings in Europe, Middle East \& Far East [9]

\subsection{Comparison of the results of the enlarged macro calculation of the cost of the construction $1 \mathrm{~m} 2$ area of the MIBC with world analogues}

The most expensive project in «Moscow City» was the two towers of the Federation Towers complex, whose total cost of construction amounted to 1.2 billion dollars. The total area of Federation Towers is $442915 \mathrm{~m}^{2}$. The estimated cost of $1 \mathrm{~m}^{2}$ Federation Towers is $\$$ 1.2 bln. $/ 442915 \mathrm{~m}^{2}=2710 \$ / \mathrm{m}^{2}$. Table 3 presents the results of a comparison of the complex Federation Towers construction economy with analogues in the UAE, Taiwan, USA. Analysis of Table 3 shows that the estimated cost of building $1 \mathrm{~m}^{2}$ area of Federation Towers (Moscow) is close to the upper limit of the cost range for the analogues in the UAE and the USA.

Table 3. Comparison of the estimated cost of building $1 \mathrm{~m}^{2}$ area of Federation Towers (Moscow) with the cost of building $1 \mathrm{~m}^{2}$ area of analogous high-rise buildings in the UAE, Taiwan, USA

\begin{tabular}{|l|c|c|c|c|c|}
\hline $\begin{array}{l}\text { Country, city, } \\
\text { high-rise building }\end{array}$ & $\begin{array}{c}\text { Height to } \\
\text { the roof, } \\
\text { m. } \\
\text { without } \\
\text { spire) }\end{array}$ & $\begin{array}{c}\text { Floors } \\
\text { amount }\end{array}$ & $\begin{array}{c}\text { Total cost of } \\
\text { building, } \\
\$ \text { mln. (year) }\end{array}$ & $\begin{array}{c}\text { Total area of } \\
\text { skyscraper } \\
\text { premises, } \mathrm{m}^{2}\end{array}$ & $\begin{array}{c}\text { Estimated cost } \\
\text { of construction } \\
1 \mathrm{~m}^{2} \text { area, } \$ \mathrm{~m}^{2}\end{array}$ \\
\hline $\begin{array}{l}\text { Russia, Moscow, } \\
\text { «Federation Towers» }\end{array}$ & 373.8 & 93 & $\approx 1200(2016)$ & 442915 & $\approx 2710$ \\
\hline $\begin{array}{l}\text { UAE, Dubai, } \\
\text { «Burj Khalifa», }\end{array}$ & 584.5 & 163 & $\approx 1500(2010)$ & 309473 & $\approx 4847$ \\
\hline $\begin{array}{l}\text { Taiwan, Taipei, } \\
\text { «Taipei 101» }\end{array}$ & 438.0 & 101 & $\approx 1700(2004)$ & 357719 & $\approx 4752$ \\
\hline $\begin{array}{l}\text { USA, New York, } \\
\text { «Empire State } \\
\text { Building» }\end{array}$ & 373.1 & 102 & $\begin{array}{c}40.949(1931) \\
\text { or } 499.577 \\
(2017) \\
\text { considering } \\
\$ 1_{1925}= \\
=\$ 12.20_{2017}\end{array}$ & 208879 & $\begin{array}{c}2391.2(2017) \\
\text { or } \\
\text { considering } \\
\$ 1_{1925}= \\
=\$ 12.20_{2017}\end{array}$ \\
\hline
\end{tabular}




\subsection{Assessment of the possibility of the MIBS construction project recoupment by the attracted business}

Table 4 presents some known data [10] describing the business of the owners of Moscow International Business Center (MIBC) high-rise buildings.

Table 4. Information about some objects of MIBC

\begin{tabular}{|c|c|c|c|c|}
\hline \multirow{2}{*}{ Data } & \multicolumn{4}{|c|}{ Some high-rise buildings, included in MIBC } \\
\hline & Federation Towers & $\mathrm{OKO}$ & Mercury City Tower & City of Capitals \\
\hline Owner & $\begin{array}{c}\text { AEON } \\
\text { (R. Trotsenko) }\end{array}$ & $\begin{array}{l}\text { Capital Group } \\
\text { (V. Doronin, P. } \\
\text { Te, E. Berman) }\end{array}$ & $\begin{array}{c}\text { Mercury } \\
\text { Development } \\
\text { (I. Kesaev) } \\
\end{array}$ & $\begin{array}{l}\text { Capital Group } \\
\text { (V. Doronin, P. } \\
\text { Te, E. Berman) } \\
\end{array}$ \\
\hline Estimated cost & $\$ 1,2$ bln. & $\$ 0,7$ bln. & $\$ 0,7-1,3$ bln. & No data \\
\hline $\begin{array}{l}\text { Total area, } \\
\text { thousands } \mathrm{m}^{2}\end{array}$ & 443 & 250 & 174 & 288 \\
\hline $\begin{array}{l}\text { Office area, } \\
\text { thousands } \mathrm{m}^{2}\end{array}$ & 287 & 115 & 89 & 72 \\
\hline $\begin{array}{l}\text { Residential } \\
\text { area, thousands } \\
\mathrm{m}^{2}\end{array}$ & 78 & 135 & 22 & 101 \\
\hline $\begin{array}{l}\text { Number of } \\
\text { apartments }\end{array}$ & 212 & 588 & 137 & 470 \\
\hline Rental rate & $\$ 400-650$ & $\$ 540-560$ & $\$ 400-430$ & $\$ 650-940$ \\
\hline Vacancy & $8 \%$ & $70 \%$ & $55 \%$ & $7 \%$ \\
\hline $\begin{array}{l}\text { Estimated cost } \\
\text { of Sale, } \$ / \mathrm{m}^{2}\end{array}$ & No data & $\begin{array}{l}360 \text { thousands } \\
\text { rub. }\end{array}$ & $\$ 8000$ & $\$ 13000$ \\
\hline Purchasers & $\begin{array}{c}\text { VTB Bank, } \\
\text { Sberbank of Russia, } \\
\text { Mercury }\end{array}$ & Moscow City Hall & $\begin{array}{c}\text { JTI, } \\
\text { NorNickel }\end{array}$ & $\begin{array}{c}\text { Renaissance } \\
\text { Credit, Capital } \\
\text { Group } \\
\end{array}$ \\
\hline
\end{tabular}

Taking into account the data from table 4, the following conclusions can be drawn:

- The various buildings of MIBC have different investment attractiveness for the Moscow business.

- Having an estimated construction cost of $1 \mathrm{~m}^{2}$ area of about 2700-2800 \$/ $\mathrm{m}^{2}$ and selling areas at $\$ 6000-13000 \$ / \mathrm{m}^{2}$, the owners have the opportunity not only to compensate the investment expenses, but also to make a profit.

- At the same time, information about vacancies leads to the conclusion that the refund of investments will be long and difficult.

\section{Discussion}

The article [11] provides information on the structure of the foreign direct investment distribution in the Russian economy (Table 5). The data of the Central Bank of Russia illustrate the thesis that only Moscow is an object of investors' interest (including Russian investors, who return finances from offshores). The main focus of investment interest, that also includes the field of high-rise construction (up to $68 \%$ of the total investment in Russia), is concentrated in Moscow. Foreign investors are significantly less interested in St. Petersburg (5-8 \%). The Sverdlovsk oblast (the regional center - Yekaterinburg) received in 2011-2015 only 0.55-3.21\% of foreign direct investments. And this despite the fact that Yekaterinburg is the third city in the country by the number of high-rise buildings. Probably, this fact confirms the thesis that there is practically no economic interest of economic entities in the management of high-rise construction in Russian cities. It is also important that the density of people in Russian cities is low enough (table 2), and investors are not interested in 
investing in projects that are attractive from a position of marketing, but ineffective in terms of capital productivity.

Table 5. Regional structure of foreign direct investments inflow (part of the table [11])

\begin{tabular}{|c|c|c|c|c|}
\hline \multirow{2}{*}{$\begin{array}{l}\text { Federal Districts (FD) } \\
\text { and Federal Subjects } \\
\text { of Russian Federation }\end{array}$} & 2011 & 2012 & 2013 & $\begin{array}{l}07.2014 \ldots \\
\ldots 06.2015\end{array}$ \\
\hline & \multicolumn{4}{|c|}{ Regions shares in foreign direct investments inflow, $\%$} \\
\hline Russian Federation & 100.0 & 100.0 & 100.0 & 100.0 \\
\hline Central FD & 73.44 & 59.21 & 62.51 & 64.51 \\
\hline Moscow & 68.01 & 51.27 & 55.82 & 53.98 \\
\hline North-West FD & 6.91 & 12.89 & 10.66 & 11.47 \\
\hline St. Petersburg & 4.48 & 7.84 & 6.74 & 5.63 \\
\hline \multicolumn{5}{|c|}{ 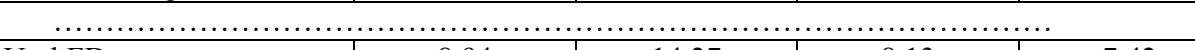 } \\
\hline Ural FD & 8.94 & 14.27 & 8.13 & 7.42 \\
\hline Sverdlovsk oblast & 0.55 & 3.21 & 0.56 & 0.69 \\
\hline
\end{tabular}

\section{Conclusions}

According to the results above we can formulate the following conclusions.

1. By the end of 2017, only 40 buildings with a height of more than $150 \mathrm{~m}$ (less than $1 \%$ of analogues in the world) have been built or are in the active phase of construction in Russian cities; most of them in Moscow, St. Petersburg and Yekaterinburg because of the high level of fiscal capacity.

2. The cost structure of building $1 \mathrm{~m}^{2}$ area in different countries of the world significantly varies. The Russian experience of high-rise construction (on the example of Federation Towers in MIBC) is close to analogues in the UAE and Saudi Arabia.

3. The estimated cost of building $1 \mathrm{~m}^{2}$ of Federation Towers in MIBC is $2710 \mathrm{US} \$ / \mathrm{m}^{2}$.

4. The possibility of recoupment of MIBC construction project by the involved business exists in theory, but is very difficult in practice.

5. Regional high-rise construction projects in Russia have few chances of development. The reason is a large volume and a continuous refund of the required investment.

\section{References}

1. http://www.skyscrapercenter.com/ (Accessed 31.10.2017)

2. http://psa.gov.ph/content/philippine-population-density-based-2015-census-population (Accessed 2.11.2017)

3. http://global.ctbuh.org/resources/papers/download/1269-building-cost-and-eco-costaspects-of-tall-buildings.pdf (Accessed 7.11.2017)

4. P. de Jong, and S. Van Oss. Hight Rise Ability. In 14th Annual European Real Estate Society Conference. ERES: Conference. London, UK, (2007).

5. http://skyscraperpage.com/diagrams/?cityID=14 (Accessed 13.11.2017)

6. http://citymoscow.ru/ (Accessed 14.12.2017)

7. https://www.bfm.ru/news/290715 (Accessed 14.12.2017)

8. D. Langdon, S. Watts. Building, 6 (2002)

9. S. Watts, D. Langdon, CTBUH Journal, 3 (2010)

10. http://www.forbes.ru/kompanii/infrastruktura/infographics/311921-gorod-ambitsiikomu-prinadlezhit-moskva-siti (Accessed 4.01.2018)

11. Kuznetsova O. International processes. Issue 14. № 3 (in Russian) 